\title{
THE EFFECT OF PROFITABILITY, LEVERAGE, FIRM SIZE, POLITICAL CONNECTION AND FIXED ASSET INTENSITY ON TAX AVOIDANCE (EMPIRICAL STUDY ON MINING COMPANIES LISTED IN INDONESIA STOCK EXCHANGE 2015-2017)
}

\author{
Ayu Prapitasari, Lili Safrida \\ Universitas Lambung Mangkurat Banjarmasin, Indonesia \\ ayuprapitasari8@gmail.com
}

\begin{tabular}{|c|c|}
\hline INFO ARTIKEL & ABSTRAK/ABSTACT \\
\hline $\begin{array}{l}\text { Histori Artikel: } \\
\text { Tgl. Masuk : } 02 \text { Juli } 2019 \\
\text { Tgl. Diterima : } 30 \text { September } 2019 \\
\text { Tersedia Online : } 30 \text { September } 2019 \\
\text { Keywords: } \\
\text { Tax avoidance, profitability, } \\
\text { leverage, company size, } \\
\text { political connection, intensity of } \\
\text { fixed assets }\end{array}$ & $\begin{array}{l}\text { The purpose of this reserch is to examine and analyze (1) } \\
\text { the influenceof profability on tax avoidance, (2) the influence } \\
\text { of leverage on tax avidance, (3) the influence of company } \\
\text { size on tax avoidance, (4) the influence of political } \\
\text { connection on tax avoidance, and (5) the influence of } \\
\text { intensity of fixed assets on tax avoidance } \\
\text { The object of this research used mining company listed in } \\
\text { BEl in 2015-2017. Companies which used as sample were } \\
17 \text { samples for } 3 \text { years of observation. The technique of } \\
\text { data analysis used logistic regression analysis } \\
\text { The results of this research shows that profitability has a } \\
\text { positive influence on tax avoidance because high } \\
\text { profitability will ncrease the taxes. On the other hand, } \\
\text { leverage, company size, political connection, and intensity } \\
\text { of fixed assets have negative influene on tax avoidance } \\
\text { because the company is considering to long term effect on } \\
\text { performing tax avoidance }\end{array}$ \\
\hline
\end{tabular}

\section{PENDAHULUAN}

Indonesia adalah negara berkembang yang selalu berusaha untuk melaksanakan pengembangan nasional disegala sektor dan mensejahterakan masyarakatnya. Salah satu upaya yang dilakukan untuk membiayai rencana pembangunan itu didapat dari penerimaan pajak. Pajak menjadi salah satu pendapatan yang memiliki potensi yang tinggi dan masuk dalam urutan yang pertama dalam menyumbang kas pendapatan pada Anggaran Pendapatan dan belanja Negara (APBN) bila disepadankan dengan pendapatan dari sektor lain. Pendapatan yang diperoleh dari pajak dapat digunakan untuk membiayai peningkatkan pendidikan dan kesejahteraan rakyat, menjaga keamanan dan stabilitas negara, membangun infrastruktur untuk kebutuhan bersama, serta meningkatkan pembangunan di berbagai daerah.

Pembayaran pajak merupakan wujud nyata oleh wajib pajak dalam memenuihi kewajiban pajaknya dan secara langsung berpartisipasi dalam pelaksanaan pembiayaan untuk pembangunan negara. Hal yang berbeda dirasakan oleh pemilik usaha atau wajib pajak badan yang terus berupaya menekan biaya-biaya usaha, termasuk beban pajak. Pajak bagi perusahaan adalah komponen yang dapat mengurangi keuntungan yang didapat perusahaan. Beban pajak yang besar ditanggung oleh perusahaan membuat perusahaan melakukan manajemen pajak agar dapat mengurangi beban pajak ditanggung perusahaan. 
Usaha untuk memperkecil beban pajak dilakukan dengan cara penghindaran pajak. Penghindaran pajak merupakan praktik yang dijalankan dengan tujuan mengurangi beban pajak yang harus dibayarkan, yang bersifat legal tanpa melanggar peraturan perpajakan dengan memanfaatkan kelemahan peraturan (loopholes) (Dewi \& Jati, 2014). Kegiatan ini memiliki risiko yang harus ditanggung oleh perusahaan diantaranya denda serta buruknya pandangan perusahaan dimata masyarakat. Jika penghindaran pajak yang dilakukan menyimpang dan melanggar peraturan dan hukum yang ditetapkan maka praktik tersebut dapat dikategorikan sebagai penggelapan pajak.

Pemerintah selalu meningkatkan target penerimaan pajak setiap tahunnya. Tetapi realisasi dari target penerimaan pajak tersebut belum dapat tercapai. Hal dikarenakan pemungutan pajak di Indonesia masih belum optimal karena masih memiliki banyak kendala (Dharma \& Ardiana, 2016). Selain itu, penyebab yang mempengaruhi belum tercapainya target penerimaan pajak disebabkan oleh usaha yang dilaksanakan oleh para wajib pajak khususnya wajib pajak perusahaan yang berusaha untuk mengurangi beban pajak.

Praktik penghindaran pajak menyebabkan banyak kerugian bagi negara hingga ratusan miliar rupiah setiap tahun dari pendapatan negara sektor pajak. Adanya penurunan penerimaan pajak akan menghambat pembangunan yang telah direncanakan. Masyarakat menilai penghindaran pajak sebagai tindakan yang sangat merugikan bagi kepentingan bersama (Lestari \& Putri, 2017). Masyarakat menilai saharusnya perusahaan dapat berperan besar dalam mewujudkan kesejahteraan masyarakat luas melalui pembayaran pajak. Sektor perusahaan yang berpotensi dan terkadang melakukan tindakan penghindaran pajak salah satunya adalah sektor pertambangan.
Pada penelitian sebelumnya masih ditemukan hasil penelitian yang bertentangan, hal tersebut mendorong penulis untuk mengadakan kembali penelitian tentang penghindaran pajak. Pada penelitian Rinaldi dan Cheisviyanny (2015), Putri dan Putra (2017), Amelia (2015), Dharma dan Adriana (2016), dan Annisa (2017) menunjukan hasil tidak konsisten, hal tersebut melatarbelakangi peneliti untuk mengadakan penelitian kembali yang bertujuan untuk mendapatkan kejelasan variabel-variabel yang memengaruhi perusahaan untuk menjalankan penghindaran pajak.

Penelitian ini adalah replikasi dari penelitian yang sebelumnya dilaksanakan oleh Annisa (2017) yang meneliti tentang pengaruh Return On Asset, Leverage, Ukuran perusahaan dan Koneksi Politik Terhadap Penghindaran Pajak Pada Perusahaan Manufaktur yang terdaftar di BEI Periode Tahun 2012-2015. Berdasarkan hasil penelitian yang tidak konsisten mendorong peneliti untuk menguji kembali konsistensi hasil penelitian terdahulu serta mengembangkan penelitian yang telah dilakukan sebelumnya dengan menambahkan variabel yang berbeda yaitu intensitas aset tetap.

Sektor pertambangan dipilih menjadi sampel pada penelitian ini karena sektor pertambangan merupakan salah satu penyumbang pajak terbesar di Indonesia dan perusahaan pertambangan beroperasi dalam skala besar, baik dalam tingkat nasional maupun internasional. Perusahaan pertambangan memiliki total asset yang besar karena dalam menjalankan kegiatan utamanya yaitu pencarian, penambangan (penggalian), pengolahan, pemanfaatan dan penjualan bahan-bahan galian membutuhkan asset yang tidak sedikit. Kegiatan operasional perusahaan tambang tersebut yang menyebabkan besarnya investasi dalam kepemilikan asset pada perusahaan pertambangan.

Tujuan dari dilakukannya penelitian ini adalah untuk menguji dan menganalisis 
secara empiris: 1). Untuk mengetahui dan menganalisis pengaruh profitabilitas terhadap penghindaran pajak 2). Untuk mengetahui dan menganalisis pengaruh leverage terhadap penghindaran pajak. 3). Untuk mengetahui dan menganalisis pengaruh ukuran perusahaan terhadap penghindaran pajak. 4). Untuk mengetahui dan menganalisis pengaruh koneksi politik terhadap penghindaran pajak. 5). Untuk mengetahui dan menganalisis pengaruh intensitas aset tetap terhadap penghindaran pajak.

Berdasarkan penjelasan yang telah disampaikan, peneliti tertarik untuk melakukan penelitian yang berjudul "Pengaruh Profitabilitas, Leverage, Ukuran Perusahaan, Koneksi Politik dan Intensitas Aset Tetap Terhadap Penghindaran Pajak (Studi Empiris Pada Perusahaan Pertambangan yang Terdaftar di Bursa Efek Indonesia Tahun 2015-2017)"

\section{KERANGKA TEORITIS DAN PENGEMBANGAN HIPOTESIS}

\section{Agency Theory (Teori Agensi)}

Agency theory adalah kontak yang ada diantara pemilik (principle) dan manajer (agent). Pemilik (principle) memperkerjakan manajemen (agent) untuk melaksanakan tugas dan kepentingan pemilik (principle), termasuk memberikan wewenang terhadap manajemen (agent) untuk mengambil untuk pencapaian tujuan utama perusahaan yaitu mencapai target laba yang ditetapkan. Adanya teori agensi berawal pada sebuah perjanjian suatu hubungan kerja antara pemilik yang berwenang dalam perusahaannya dengan manajemen sebagai pihak diberikan kepercayaan untuk menggerakan operasional perusahaan. Sebagai pihak yang lebih mengetahui kondisi perusahaan yang sebenarnya membuat manajemen berkewajiban untuk memberi informasi yang dimilikinya kepada pemilik perusahaan.
Manajer terkadang tidak melaporan kondisi perusahaan yang sesungguhnya karena berusaha untuk menutupi kekurangan perusahaan serta berusaha untuk menjaga kinerja manajer agar terlihat baik oleh pemilik perusahaan. Manajemen seharusnya bertanggungjawab untuk memaksimalkan potensi laba yang dapat dimiliki perusahaan dan kemudian akan menerima kompensasi sesuai dengan kesepakatan yang telah disetujui dengan pemilik (Amelia, 2015). Tindakan yang dilakukan manajer ini disebabkan oleh perbedaan kepentingan antara pemilik perusahaan dengan manajer yang memicu munculnya masalah keagenan seperti pengeluaran yang melebihi anggaran, salah dalam pengambilan keputusan dan perbedaan informasi yang diterima.

Adanya perbedaan kepentingan antara pemilik dan manajer tentu saja akan berpengaruh pada berbagai hal yang memiliki keterkaitan dengan kondisi perusahaan, diantaranya adalah kebijakan yang diambil perusahaan dalam mengelola pajak perusahaan. Indonesia menerapkan sistem perpajakkan self assessment system yang memberi kesempatan bagi wajib pajak khusunya wajib pajak perusahaan untuk mengkalkulasi dan melaporkan sendiri besaran pajak yang ditanggungnya. Sistem tersebut membuka peluang bagi manajemen (agent) untuk melakukan kecurangan seperti membuat pendapatan kena pajak menjadi lebih kecil sehingga akan mempengaruhi jumlah pajak tertanggung yang wajib dibayar oleh perusahaan menjadi lebih kecil pula.

\section{Penghindaran pajak}

Tingkat persentase CETR yang hampir mencapai tarif pajak penghasilan badan sebesar 25\% menunujukan rendahnya tingkat penghindaran pajak yang dilakukan perusahaan, apabila tingkat persentase CETR semakin rendah maka hal tersebut mengisyaratkan bahwa tingginya potensi praktik penghindaran pajak yang dilakukan perusahaan. Menurut Puspita dan Febrianti (2017) 
Perhitungan proksi Cash Effective Tax Rate (CETR) dilakukkan menggunakan rumus:

$$
\text { CETR }==\frac{\text { Pembayaran }}{\text { Laba Sebelum }}
$$

\section{Profitabilitas}

Rasio profitabilitas dapat menggambarkan efisiensi perusahaan untuk menghasilkan laba yang bersumber dari tingkat penggunaan asset atau ekuitas perusahaan. Pada penelitian ini memilih ROA karena dapat memperhitungkan tingkat profitabilitas dan memberikan gambaran kemampuan perusahaan untuk mengelola aset yang bersumber dari modal sendiri ataupun yang didapat dari modal pinjaman. Pengukuran profitabilitas dengan menggunakan rasio ROA dapat diukur menggunakan rumus berikut:

$$
\mathrm{ROA}=\frac{\text { Laba Bersih }}{\text { Total Asset }}
$$

\section{Leverage}

Rasio leverage adalah rasio yang dapat menggambarkan besarnya utang yang dimanfaatkan untuk mendanai operasional perusahaan. Selain itu, leverage dapat digunakan sebagai gambaran untuk menunjukkan struktur modal yang dimiliki perusahaan agar dapat mengetahui seberapa besar resiko utang tidak tertagih. Pengukuran leverage dangan menggunakan rasio DER dapat diukur dengan rumus berikut:

$$
\text { DER }=\frac{\text { Total Utang }(\text { Debt })}{\text { Total Ekuitas }(\text { Eauitv })}
$$

\section{Ukuran perusahaan}

Ukuran perusahaan adalah pengkategorian besar atau kecilnya perusahaan berdasarkan jumlah asset. Umumnya ukuran perusahaan diproyeksikan dari kepemilikan total aset karena kuantitas total asset memiliki jumlah yang paling besar apabila disejajarkan dengan variabel keuangan lainnya. Ukuran perusahaan dapat diukur dengan rumus:

$$
\text { Size }=\operatorname{Ln}(\text { Total Aset })
$$

\section{Koneksi Politik}

Perusahaan diduga memiliki koneksi politik jika terdapat pemilik saham (seseorang yang memiliki minimal 10\% kepimilikan dari total saham dengan hak suara) maupun pimpinan perusahaan (CEO, Presiden, wakil presiden, ketua, dan sekretaris) yang merupakan anggota parlemen, menteri, atau orang yang memiliki hubungan khusus dengan politisi pada suatu partai politik atau pemerintahan. Kepemilikan langsung oleh pemerintah juga dapat mempengaruhi adanya koneksi politik pada perusahaan.

Menurut Purwanti dan Sugiyarti (2017) pada penentuan kepemilikan pemerintah digunakan variabel dummy untuk mengkuantitatifkan data kualitatif dengan memberi angka 1 untuk perusahaan yang memiliki koneksi politik dan nilai 0 jika tidak memiliki koneksi politik.

\section{Intensitas aset tetap}

Intensitas asset tetap merupakan indikator yang dapat memberikan gambaran besarnya investasi yang dimiliki perusahaan yang berbentuk asset tetap. Menurut Purwanti dan Sugiyarti (2017) Intensitas aset didapat dari membandingkan total aset tetap dengan

\begin{tabular}{|c|c|}
\hline Intensitas & Total Aset Tetap x 100\% \\
\hline Asset Tetap & Total Aset \\
\hline
\end{tabular}
jumlah total aset yang ada di perusahaan. Intensitas asset tetap diperhitungkan dengan rumus berikut:

\section{KERANGKA TEORITIS DAN PENGEMBANGAN HIPOTESIS}

\section{Pengaruh Profitabilitas Terhadap Penghindaran Pajak}

Perusahaan yang memiliki profitabilitas tinggi memiliki kesempatan untuk memposisikan diri dalam tax planning yang mengurangi jumlah beban kewajiban perpajakan (Prakosa, 2014). Laba yang meningkat mengakibatkan profitabilitas perusahaan juga meningkat, sehingga jumlah pajak yang harus 
dibayarkan juga meningkat atau dapat dikatakan ada kemungkinan upaya dari perusahaan untuk melakukan penghindaran pajak. ROA dapat mengukur keuntungan bersih yang diperoleh dari penggunaan aset. Semakin tinggi nilai dari ROA, berarti semakin tinggi nilai dari laba bersih perusahaan dan semakin tinggi profitabilitasnya

Dengan demikian penulis merumuskan bahwa ROA berpengaruh Positif terhadap penghindaran pajak, karena perusahaan-perusahaan yang nilai profitabilasnya tinggi tersebut terdapat kemungkinan bahwa perusahaan akan memperkecil pajak yang seharusnya dibayarkan. Berdasarkan hal tersebut dapat dirumuskan ke dalam hipotesis sebagai berikut:

$H_{1}$ : Profitabilitas berpengaruh positif terhadap terhadap penghindaran pajak

\section{Pengaruh Leverage terhadap \\ Penghindaran Pajak}

Jumlah utang yang dimiliki oleh perusahaan mengakibatkan bunga yang harus ditanggung oleh perusahaan semakin bertambah. Beban bunga yang muncul dari kepemilikan utang pada perusahaan mengakibatkan berkurangnya jumlah pajak yang harus dibayarkan oleh perusahaan karena beban bunga menjadi pengurang laba bersih perusahaan sehingga keuntungan maksimal dapat dicapai.

Jika perusahaan menggunakan utang sebagai sumber pendanaan maka laba kena pajak yang ditanggung perusahaan cenderung lebih kecil jika dibandingkan dengan sumber pendanaan yang diperoleh dari penerbitan saham perusahaan, sehingga peluang perusahaan untuk melakukan penghindaran pajak menjadi lebih besar (Surbakti, 2012). Berdasarkan hal tersebut dapat dirumuskan ke dalam hipotesis sebagai berikut:

\section{$\mathrm{H}_{2}$ : Leverage berpengaruh positif terhadap penghindaran pajak}

\section{Pengaruh Ukuran Perusahaan terhadap Penghindaran Pajak}

Menurut Dewi \& Noviari (2017) perusahaan besar yang melakukan operasi perusahaan antar negara juga memiliki kecenderungan yang lebih tinggi untuk melakukan penghindaran pajak jika dibandingkan dengan perusahaan yang beroperasi lintas domestik, karena perusahaan dapat melakukan transfer laba ke perusahaan yang terdapat di negara lain, dimana negara tersebut memungut tarif pajak yang lebih rendah jika dibandingkan dengan negara lainnya. Selain itu perusahaan besar juga memiliki transaksi yang kompleks sehingga akan membuka celah untuk melakukan penghindaran pajak.

Dengan demikian, penulis merumuskan bahwa Ukuran Perusahaan berpengaruh positif terhadap penghindaran pajak karena ukuran perusahaan yang besar akan menarik perhatian pemerintah sesuai dengan pajak yang sesuai. Berdasarkan hal tersebut dapat dirumuskan ke dalam hipotesis sebagai berikut

$\mathrm{H}_{3}$ : Ukuran Perusahaan berpengaruh positif terhadap penghindaran pajak

\section{Pengaruh Koneksi Politik terhadap Penghindaran Pajak}

Perusahaan yang berkoneksi politik dianggap tidak mungkin melakukan penghindaran pajak, hal ini yang membuat kemungkinan perusahaan diperiksa menjadi kecil karena kemungkinan diperiksa kecil membuat perusahaan cenderung melakukan penghindaran pajak. Selain itu, keuntungan yang dapat diperoleh perusahaan yang memiliki koneksi politik adalah pinjaman dapat diperoleh dengan lebih mudah, Pemeriksaan pajak yang rendah membuat perusahaan tidak takut untuk melakukan perencaan pajak yang menyebabkan laporan keuangan perusahaan tidak transparan. Berdasarkan hal tersebut dapat dirumuskan ke dalam hipotesis sebagai berikut

$\mathrm{H}_{4}$ : Koneksi politik berpengaruh positif terhadap penghindaran pajak

Pengaruh Intensitas Aset Tetap terhadap Penghindaran Pajak 
Intensitas aset tetap merupakan bagian dalam aset tetap yang terdapat pos bagi perusahaan untuk menambahkan beban penyusutan yang ditimbulkan aset tetap sebagai pengurang penghasilan, jika perusahaan memiliki aset tetap yang besar maka laba yang dimiliki akan lebih kecil karena terdapat beban penyusutan yang terdapat dalam aset tetap yang dapat mengurangi laba (Purwanti \& Sugiyarti, 2017).

Perusahaan yang memiliki aset tetap memungkinkan perusahaan untuk memotong pajak akibat adanya penyusutan pada asset tetap yang terjadi setiap tahunnya. Hal tersebut mengindikasikan bahwa penghindaran pajak yang dapat dilakukan perusahaan semakin tinggi. Berdasarkan hal tersebut dapat dirumuskan ke dalam hipotesis sebagai berikut:

$H_{5}$ : Intensitas asset tetap berpengaruh positif terhadap penghindaran pajak.

\section{METODOLOGI PENELITIAN}

\section{Ruang Lingkup Penelitian}

Ruang lingkup yang terdapat pada penelitian ini merupakan hubungan antara profitabilitas, leverage, ukuran perusahaan, koneksi politik, dan intensitas aset tetap pada perusahaan pertambangan

\section{Jenis Penelitian}

Jenis penelitian ini merupakan penelitian kuantitatif asosiatif dengan tipe kausalitas karena penelitian ini bertujuan untuk menggambarkan dan menguji hubungan dua variabel atau lebih (Sugiyono, 2017)

\section{Tempat/Lokasi Penelitian.}

Penelitian ini dilaksanakan pada perusahaan pertambangan yang terdaftan di Bursa Efek Indonesia tahun 2015-2017?

\section{Unit Analisis}

Unit analisis penelitian ini adalar

Laporan Tahunan (Annual Report) perusahaan pertambangan yang terdaftar di Bursa Efek Indonesia periode 20152017.

\section{Populasi dan Sampel}

Populasi yang terdapat pada penelitian ini merupakan seluruh perusahaan pertambangan yang terdaftar di Bursa Efek Indonesia tahun 2015-2017. Penelitian ini dilakukan dengan teknik purposive sampling.

\section{Teknik Pengumpulan dan Analisis Data \\ Penelitian ini menggunakan data} penelitian berupa data sekunder. Sedangkan, teknik pengumpulan datanya berupa teknik dokumentasi. Analisis data yang digunakan adalah analisis statistik berupa analisis regresi logistik.

\section{Gambaran Umum Perusahaan Pertambangan di BEI Tahun 2015-2017 \\ Pertambangan adalah aktivitas eksplorasi ke dalam tanah (bumi) untuk memperoleh sesuatu berupa hasil tambang. Jumlah perusahaan pertambangan yang terdaftar pada Bursa Efek Indonesia tahun 2015-2017 sebanyak 47 perusahaan. Berdasarkan metode purposive sampling diperoleh sampel sebanyak 17 perusahaan dengan total 51 sampel untuk 3 tahun pengamatan.}

\section{HASIL DAN PEMBAHASAN Deskripsi Statistik Sampel Penelitian}

Deskripsi variabel pada sampel penelitian dilakukan dengan melihat hasil analisis statistik deskriptif untuk variabel yang menggunakan skala pengukuran rasio. Tabel 1 berikut ini menunjukkan hasil statistik deskriptif terhadap variabelvariabel yang ada pada penelitian:

Tabel 1

Hasil Statistik Deskriptif

\begin{tabular}{|l|r|r|r|r|}
\hline Var & \multicolumn{1}{|l|}{ Min } & Max & Mean & \multicolumn{1}{l|}{$\begin{array}{l}\text { Std. } \\
\text { Dev }\end{array}$} \\
\hline PP & 0,00000 & 1,00000 & 0.00027 & 0,00451 \\
Pr & 0,00023 & 0,39411 & 0,08430 & 0,91585 \\
Lev & 0,16940 & 2,87719 & 0,78654 & 0,57058 \\
UP & 27,1296 & 32,1512 & 29,1777 & 1,21370 \\
K.P & 0,0000 & 1,0000 & $.0,00075$ & .0 .00440 \\
IAT & 0,04933 & 0,45293 & 0,26887 & 0,11239 \\
Valid N & & & & \\
(listwie) & & & & \\
\hline
\end{tabular}

Sumber: Data diolah kembali (2018) 


\section{MENILAI KESELURUHAN MODEL (OVERALL MODEL FIT)}

Tabel 2

Nilai Keseluruhan Model (Overall Model Fit)

Perbandingan Nilai -2LL Awal dengan 2LL Akhir

\begin{tabular}{|c|l|l|l|}
\hline $\begin{array}{c}\text { Step } \\
0\end{array}$ & -2 Log & Step & -2 Log \\
& Likehood & 1 & Likehood \\
\cline { 2 - 2 } & 59,945 & & 46,417 \\
\hline
\end{tabular}

Sumber: Data diolah kembali (2018)

Tabel 2 diatas menunjukkan nilai yang terdapat pada -2 Log likehood awal (Step 0) sebesar 59,945. Setelah kelima variabel independen dimasukkan terjadi perubahan pada nilai -2 Log Likehood akhir (Step 2) menjadi 46,417. Adanya perubahan tersebut terjadinya penurunan nilai sebesar 13,528 pada nilai -2 Log Likehood, hal tersebut menunjukkan bahwa model diperbolehkan dengan data atau model regresi yang digunakan adalah model yang baik secara keseluruhan.

\section{MENGUJI KELAYAKAN MODEL REGRESI}

Tabel 3

Hasil Pengujian Kelayakan Model Regresi

Hosmer and Lemeshow Test

\begin{tabular}{|c|r|r|c|}
\hline Step & $\begin{array}{c}\text { Chi- } \\
\text { square }\end{array}$ & Df & Sig. \\
\hline 1 & 4,708 & 8 & 0,788 \\
\hline
\end{tabular}

Sumber: Data diolah kembali (2018)

Tabel 3 menunjukkan nilai yang pada Chi-Square sebesar 4,708 dengan signifikansi 0,788 . Nilai signifikansi yang terdapat pada tabel lebih besar dari 0,05 $(0,788>0,05)$ hal tersebut menunjukkan bahwa model mampu memperkirakan nilai observasinya.

\section{HASIL UJI KOEFISIEN DETERMINASI \\ Tabel 4}

Hasil Uji Koefisien Determinasi

\begin{tabular}{|c|c|c|c|}
\hline Step & $\begin{array}{c}-2 \text { Log } \\
\text { likelihood }\end{array}$ & $\begin{array}{c}\text { Cox \& Snell } \\
R \text { Square }\end{array}$ & $\begin{array}{c}\text { Nagelkerke } \\
R \text { Square }\end{array}$ \\
\hline 1 & $46,417^{a}$ & 0,233 & 0,337 \\
\hline
\end{tabular}

Sumber: Data diolah kembali (2018)
Hasil koefiisien determinasi memberi informasi nilai koefisien determinasi yang diperlihatkan oleh Negelkerke $R$ Square sebesar 0,337. Tabel tersebut menunjukkan bahwa variable dependen yang dapat dijelaskan oleh variable dependen sebesar $33,7 \%$, sementara itu $66,3 \%$ sisanya menjelaskan variabel-variabel lain diluar dari model penelitian.

\section{ESTIMASI PARAMETER}

Pada estimasi parameter dapat dilihat dari output Variable In the Equation yang memberikan nilai koefisiem regresi dan nilai signifikansinya (Ghozali, 2016). Terbentuknya model regresi dari penelitian ini disajikan melalui tabel 5 berikut ini:

\section{Tabel 5}

Hasil Uji Koefisien Regresi Logistik

\begin{tabular}{|c|c|c|c|c|c|c|c|}
\hline & B & S.E. & Wald & $\begin{array}{c}\text { D } \\
f\end{array}$ & Sig. & $\begin{array}{r}\text { Exp } \\
(B)\end{array}$ & Ket \\
\hline PR & 13,321 & 5,147 & 6,698 & 1 &, 010 & 1,000 & B \\
\hline Lev & 1,104 &, 683 & 2,613 & 1 &, 106 & 1,000 & TB \\
\hline UP &,- 159 &, 327 &, 238 & 1 &, 626 & 1,000 & TB \\
\hline KP & 1,162 & 1,071 & 1,177 & 1 &, 278 & 3,196 & TB \\
\hline IAT & $-6,868$ & 3,538 & 3,768 & 1 &, 052 & 1,000 & TB \\
\hline Con & 2,350 & 9,299 &, 064 & 1 &, 801 & 10,48 & \\
ts & & & & & & 3 & \\
\hline
\end{tabular}

Sumber: Data diolah kembali (2018)

\section{PENGARUH PROFITABILITAS TERHADAP PENGHINDARAN PAJAK}

Hipotesis pertama penelitian ini menyatakan profitabilitas berpengaruh positif terhadap penghindaran pajak. Hasil pengujian hipotesis tersebut mengungkapkan bahwa variabel profitabilitas berkoefisien positif sebesar 13,321 dengan tingkat signifikansi 0,010 yang kurang dari dari 0,05 . Hasil tersebut menunjukkan bahwa penelitian menerima $\mathrm{H} 1$, sehingga dapat disimpulkan bahwa profitabilitas berpengaruh positif terhadap penghindaran pajak. Hal itu menunjukkan bahwa profitabilitas menjadi faktor yang dapat mempengaruhi manajemen perusahaan dalam melakukkan praktik penghindaran pajak 
Profitabiltas yang tinggi pada suatu perusahaan secara maksimal menunjukkan bahwa perusahaan dapat mengelola asset secara efisien untuk memperoleh laba. Laba yang dimiliki akan dikelola sebaik mungkin dengan melakukan perencanaan pajak. Perencanaan dilakukan dengan cara memaksimalkan beban-beban yang dapat menurunkan penghasilan kena pajak seperti amortisasi dan beban penelitian dan pengembangan. Perusahaan yang memiliki tingkat profitabilitas yang tinggi tentu saja membayar pajak lebih tinggi daripada perusahaan yang memiliki profitabilitas rendah. Maka perusahaan yang memiliki tingkat profitabilitas yang tinggi memiliki kecenderungan melakukan praktik penghindaran pajak.

\section{PENGARUH LEVERAGE TERHADAP PENGHINDARAN PAJAK}

Hipotesis kedua pada penelitian ini menyatakan bahwa leverage berpengaruh positif terhadap penghindaran pajak. Berdasarkan hasil pengujian hipotesis yang ada variabel leverage memiliki koefisien positif 1,104 dengan tingkat signifikansi 0,106 yang lebih dari 0,05. Hasil tersebut menunjukkan bahwa penelitian menolak $\mathrm{H} 2$, sehingga dapat disimpulkan bahwa leverage tidak berpengaruh terhadap praktik penghindaran pajak.

Kepemilikan pendanaan dari utang tidak hanya bertujuan untuk melakukan penghindaran pajak, perusahaan menganalisis adanya kemungkinan pengambilan resiko yang jauh lebih tinggi jika dibandingkan dengan keuntungan yang didapat jika melakukan penghindaran pajak. Perusahaan yang melakukan pendanaan dari utang tidak selalu bertujuan untuk melakukan penghindaran pajak, tentu saja perusahaan telah melakukan analisis mengenai kemungkinan pengambilan resiko yang lebih besar jika dibandingkan dengan keuntungan yang akan didapat perusahaan jika melakukan penghindaran pajak.

Selain itu, tingkat utang yang dimiliki suatu perusahaan telah diatur
Pemerintah dalam Peraturan Menteri Keuangan Republik Indonesia Nomor 169/PMK.010/2015 yang menetapkan bahwa perbandingan untuk hutang dan modal ditentukan maksimal sebesar empat banding satu (4:1). Pembatasan penggunaan utang yang telah diatur oleh pemerintah bertujuan untuk membatasi perusahaan agar tidak memanfaatkan utang secara berlebihan dan mendorong perusahaan untuk lebih memilih pendanaan yang berasal dari ekuitas agar tidak menimbulkan resiko kesulitan keuangan.

\section{PENGARUH UKURAN PERUSAHAAN TERHADAP PENGHINDARAN PAJAK}

Hipotesis ketiga pada penelitian ini menyatakan ukuran perusahaan berpengaruh positif terhadap penghindaran pajak. Berdasarkan hasil pengujian hipotesis yang ada variabel ukuran perusahaan memiliki koefisien negatif sebesar -0.159 dengan tingkat signifikansi 0,626 yang lebih dari 0,05. Hasil tersebut menunjukkan bahwa penelitian menolak $\mathrm{H} 3$, sehingga dapat disimpulkan bahwa ukuran perusahaan tidak berpengaruh terhadap penghindaran pajak.

Perusahaan yang dikelompokkan ke dalam ukuran yang besar (memiliki asset yang besar) dapat mempengaruhi secara signifikan menurunnya praktik penghindaran pajak yang terjadi di perusahaan, karena semakin besar ukuran suatu perusahaan maka besar pula sumber daya yang dimiliki sehingga perusahaan besar lebih mampu untuk membuat suatu perencanaan pajak yang baik.

Perusahaan tidak mau menanggung resiko bila harus menjalani proses pemeriksaan dan pandangan buruk pada perusahaan oleh masyarakat dalam jangka panjang (Merslythalia \& Lesamana, 2016). Ukuran perusahaan tidak berpengaruh terhadap penghindaran pajak karena setiap perusahaan memiliki kewajiban untuk membayar pajak, sehingga perusahaan besar maupun perusahaan kecil akan selalu dikejar oleh pihak yang berwenang jika melanggar 
ketentuan perpajakan yang berlaku. Maka perusahaan lebih memilih untuk tidak memanfaatkan kesempatan yang ada untuk melakukan penghindaran pajak karena terdapat kemungkinan menjadi perhatian masyarakat dan menjadi sasaran dari keputusan regulator (Prakosa, 2014).

\section{PENGARUH KONEKSI POLITIK TERHADAP PENGHINDARAN PAJAK}

Hipotesis keempat pada penelitian ini menyatakan koneksi politik berpengaruh positif terhadap penghindaran pajak. Berdasarkan hasil pengujian hipotesis yang ada menunjukkan bahwa variabel koneksi politik memiliki koefisien positif sebesar 1,162 dengan tingkat signifikansi 0.278 yang lebih dari 0,05 . Berdasarkan hasil tersebut penelitian menolak $\mathrm{H} 4$, dapat disimpulkan bahwa koneksi politik tidak berpengaruh terhadap penghindaran pajak.

\section{Koneksi politik berpengaruh negatif terhadap penghindaran pajak karena perusahaan akan cenderung berhati-hati pada pengambilan keputusan dan kebijakan agar tetap dapat memperoleh penghargaan dari pemerintah sebagai wajib pajak yang patuh. Kedekatan yang dimiliki oleh perusahaan dengan tokoh-tokoh politik pasti memberikan keuntungan namun perusahaan harus lebih mengutamakan efek jangka panjang yang mungkin timbul. Pandangan perusahaan yang tidak baik oleh masyarakat akan menimbulkan efek jangka panjang sehingga yang menurunkan kepercayaan dari masyarakat yang tentu saja akan menimbulkan kerugian.}

Perusahaan yang dimiliki oleh pemerintah seperti BUMN diduga tidak melakukan penghindaran pajak karena sudah diberi kepercayaan oleh Negara sebagai wajib pajak beresiko rendah berdasarkan Peraturan Menteri Keuangan Nomor 71/PMK.03/2010 2010 dan adanya peraturan perpajakan yang mengatur tentang transaksi dengan pihak yang mempunyai hubungan istimewa yaitu pasal 18 ayat 3 UU No. 36 Tahun 2008 tentang Pajak Penghasilan.

\section{PENGARUH INTENSITAS ASET TETAP TERHADAP PENGHINDARAN PAJAK}

Hipotsesis kelima pada penelitian ini menyatakan intensitas asset tetap berpengaruh positif terhadap penghindaran pajak. Berdasarkan hasil pengujian hipotesis menunjukkan bahwa variabel intensitas asset tetap menunjukan koefisien yang negatif sebesar -6,868. dengann tingkat signifikansi 0.052 yang lebih besar dari 0,05. Hasil tersebut menunjukkan bahwa penelitian menolak $\mathrm{H} 5$, dapat disimpulkan bahwa intensitas asset tetap tidak berpengaruh terhadap penghindaran pajak.

Hal ini memberi bukti memiliki intensitas asset tetap yang tinggi maupun rendah tidak menjadi faktor yang mempengaruhi manajemen perusahaan untuk melakukan penghindaran pajak. Kepemilikan asset tetap yang besar pada perusahaan tidak hanya untuk menghindari pajak tetapi untuk menjalankan operasional perusahaan. Adanya asset tetap yang banyak pada perusahaan memunculkan dampak yang beresiko seperti adanya beban pemeliharaan asset tetap, tempat penyimpanan yang besar dan risiko keusangan terhadap asset tetap membuat intensitas asset tetap kurang efisien sehingga intensitas asset tetap yang tinggi tidak mempengaruhi perusahaan dalam praktik penghindaran pajak.

Jika intensitas aset tetap perusahaan tinggi maka akan semakin kecil pajak perusahaan yang harus dibayarkan sehingga meningkatkan ketertarikan manajemen untuk melakukan praktik manajemen pajak. Namun, cost dan benefit yang diterima perusahaan tidak sebanding jika perusahaan meningkatkan investasi aset tetapnya. Menurut Jama dan Harnovinsah (2018) Hal tersebut dikarenakan adanya batasan umur aset tetap yang diakui oleh peraturan perpajakan. Pajak hanya mengakui umur aset tetap paling singkat 4 tahun sehingga nilai depresiasi yang dapat dijadikan biaya fiskal maksimal 25\%. Hal tersebut 
menjadikan manajemen mengurangi minat untuk melakukan manajemen pajak melalui peningkatan intensitas aset tetap.

\section{KESIMPULAN}

Merujuk pada hasil penelitian yang telah dikerjakan maka dapat disimpulkan hasil penelitian sebagai berikut:

1. Profitabilitas berpengaruh positif terhadap penghindaran pajak. Perusahaan yang memiliki tingkat profitabilitas yang tinggi akan membayar pajak lebih tinggi daripada perusahaan yang memiliki profitabilitas yang rendah. Maka perusahaan yang memiliki profitabilitas yang tinggi memiliki kecenderung yang lebih tinggi dalam melakukan praktik penghindaran pajak.

2. Leverage tidak berpengaruh pada penghindaran pajak karena perusahaan yang melakukan pendanaan dari utang tidak selalu bertujuan untuk melakukan penghindaran pajak, karena perusahaan telah melakukan analisis mengenai kemungkinan pengambilan resiko yang lebih besar jika dibandingkan dengan keuntungan yang akan didapat perusahaan jika melakukan penghindaran pajak

3. Ukuran perusahaan tidak berpengaruh terhadap penghindaran pajak karena perusahaan yang berukuran besar maupun perusahaan berukuran kecil dituntut untuk selalu taat terhadap peraturan yang berlaku terutama dalam peraturan perpajakan dan perusahaan tidak mau ambil resiko terhadap adanya proses pemeriksaan dan buruknya citra perusahaan dalam jangka panjang.

4. Koneksi politik tidak berpengaruh terhadap penghindaran pajak karena kedekatan yang ada diantara perusahaan dengan tokoh-tokoh politik tentu saja memberikan berbagai keuntungan namun perusahaan diharuskan untuk lebih mengutamakan dampak jangka panjang yang dapat ditimbulkan dari praktik penghindaran pajak.

5. Intensitas asset tetap tidak berpengaruh pada penghindaran pajak dikarenakan dalam mengurangi jumlah pajak yang wajib dibayar perusahaan. Kepemilikan asset tetap yang tinggi dalam perusahaan tidak semata-mata untuk menghindari pajak tetapi untuk menjalankan kegiatan operasional perusahaan.

\section{IMPLIKASI DAN KETERBATASAN}

Implikasi Teoritis

a. Profitabilitas berpengaruh terhadap penghindaran pajak pada perusahaan pertambangan yang terdaftar di Bursa Efek Indonesia Periode 2015-2017. Hasil penelitian ini mendukung teori keagenan yang menyatakan bahwa setiap individu berpegang atas dasar kepentingan mereka sendiri. Sementara itu, prinsipal menginginkan pengembalian yang tinggi atas investasi yang telah ditanamkan, sedangkan agen memiliki kepentingan lain untuk mendapatkan kompensasi yang besar untuk hasil kerjanya. Teori agensi juga memicu agen untuk meningkatkan laba perusahaan yang akan membuat pajak yang dibayarkan juga akan meningkat.

b. Pada penelitian ini belum berhasil membuktikan adanya pengaruh antara variabel Leverage, Ukuran Perusahaan, Koneksi Politik, dan Intensitas Aset Tetap terhadap penghindaran pajak pada perusahaan pertambangan yang terdaftar di Bursa Efek Indonesia Periode 2015-2017.

Implikasi Praktis

Hasil penelitian ini bagi perusahaan dapat menambah informasi terkait faktor yang dapat mepengaruhi manajemen dalam melakukan praktik penghindaran pajak yang bertujuan untuk menekan pajak yang dibayar dengan memanfaatkan 
kelemahan yang ada peraturan perpajakan.

Hasil penelitian ini bagi pemerintah, khususnya Direktorat Jendral Pajak dapat dijadikan sebagai bahan pertimbangan informasi, untuk melakukan pengawasan dan menguji lebih dalam mengenai penghindaran pajak yang dilakukan oleh perusahaan-perusahaan pertambangan di Indonesia yang bertujuan untuk meningkatkan pengawasan serta membuat keputusan dan pembuatan kebijakan di masa mendatang.

\section{Keterbatasan}

Pada penelitian ini masih terdapat keterbatasan yaitu jumlah sampel pengamatan yang digunakan relatif sedikit, hanya sejulah 51 sampel data peusahaan karena adanya pengurangan data yang disebabkan oleh tidak lengkapnya informasi yang disajikan dalam laporan keuangan perusahaan

\section{REFERENCES}

Adelina, T. (2012). Pengaruh Karakteristik Perusahaan dan Reformasi Perpajakan Terhadapa Penghindaran Pajak di Industri Manufaktur yang Terdaftar di Bursa Efek Indonesia Tahun 20082010. Skripsi.

Amelia, V. (2015). Pengaruh Ukuran Perusahaan, Leverage, Profitabilitas, Intensitas Aset Tetap, Intensitas Persediaan dan Komisasris Independen Terhadap Effective Tax Rate Studi Empiris Pada Perusahaan Manufaktur yang Terdaftar di Bursa Efek Studi Empiris Pada Perusahaan Ma. Skripsi, 41.

Ardyansyah, D., \& Zulkiha. (2014). Pengaruh Size, Leverage, Profitabilitas, Capital Intesity Ratio dan Komisaris Independen Terhadap Effective Tax Rate (ETR). Diponegoro Journal of Accounting. Vol.3, No.2, 1-9.

Brigham, E., \& Houston, J. F. (2013). Dasar-Dasar

Manajemen
Keuangan . Jakarta: Salemba Empat.

Budiman, J., \& Setiyono. (2012). Pengaruh Karakter Eksekutif Terhadap Penghinadaran Pajak . Jurnal Dalam SNA Akuntansi Unika.

Budiman, J., \& Setiyono. (2012). Pengaruh Karakteristik Eksekutif Terhadap Penghindaran Pajak (Tax Avoidance). Universitas Sultan Agung.

Dewi, N. N., \& Jati, I. K. (2014). Pengaruh Karakteristik Eksekutif, Karakteristik Perusahaan, dan Dimensi Tata Kelola Perusahaan yang Baik Pada Tax Avoidance di Bursa Efek Indonesia. ISSN : 2302-8556 E-Jurnal Akuntansi Universitas Udayana 6.2 (2014);239-260, 2.

Dewinta, I. A., \& Setiawan, P. E. (2016). Pengaruh Ukuran Perusahaan, Umur Perusahaan, Profitabilitas, Leverage, dan Pertumbuhan Penjualan Terhadap Tax Avoidance. ISSN 2302-8556 EJurnal Akuntansi Universitas UdayanaVol.14.3. Maret (2016): 1584-1613.

Dharma, I., \& Ardiana, P. (2016). Pengaruh Leverage, Intensitas Aset Tetap, Ukuran Perusahaan dan Koneksi Politik Terhadap Penghindaran Pajak. ISSN 23028556 E-Jurnal Akuntansi Universitas Udayana Vol.15.1 April (2016): 584-163, 26-27.

Ghozali, I. (2016). Aplikasi Annalisis Multivariate Dengan Program SPSS. Semarang: Badan Penerbit Universitas Diponegoro.

Hanlon, M., \& Heitzman, S. (2010). A Review of Tax Reserach. Journal of Accounting and Economics.

Harto, P., \& Puspita, R. S. (2014). Pengaruh Tata Kelola Perusahaan Terhadap Penghindaran Pajak. Diponegoro Journal Of Accounting. 
Ikhsan, A., Alfurkaniati, Safrida, L., Lubis, P. K., Dalimutnthe, M. I., \& Abdullah, I. (2016). Analisa Laporan Keuangan. Medan: Penerbit Madenatera.

Jama, A. K., \& Harnovinsah. (2018). Pengaruh Faktor Keuangan dan Intensitas Aset Tetap Terhadap Keputusan Pelaporan Keuangan dan Pajak. Jurnal Tekun. Vol 8. No. 1. Maret .

Kasmir. (2017). Analisis Laporan Keuangan. Jakarta: RajaGrafindo Persada.

Lestari, G., \& Putri, I. A. (2017). Pengaruh Corporate Governance, koneksi Politik, dan Leverage Terhadap Penghindaran Pajak. ISSN: 23028556 E-Jurnal Akuntansi Universitas Udayana Vol.18.3. Maret (2017): 2028-2054.

Martani, D. S. (2012). Akuntansi Keuangan Menengah berbasis PSAK. Jakarta: Salemba EMpat.

Nugraha, N. (2015). Pengaruuh corporate social responsibility, ukuran perusahaan, profitabilitas, Leverage, dan capitalintensitty terhadap agresivitas pajak. Jurusan Akuntansi Fakultas Ekonomika dan Bisnis Universitas Diponegoro.

Prakosa, K. B. (2014). Pengaruh Profitabilitas, Kepemilikan Keluarga, dan Corporate Governance terhadap Penghindaran Pajak di Indonesia. SNA 17 Mataram.

Purwanti, S. M., \& Sugiyarti, L. (2017). Pengaruh Intensitas Aset Tetap, Pertumbuhan Penjualan dan Koneksi Politik Terhadap Tax
Avoidance (Studi Kasus Pada Perusahaan Manufaktur Yang Terdaftar di Bursa Efek Indonesia Tahun 2012-2016). Jurnal Riset Akuntansi Keuangan, 5 (3).

Puspita, D., \& Febrianti, M. (2017). FaktorFaktor yang mempegaruhi penghindaran pajak pada perusahaan manufaktur di Bursa Efek Indonesia . Jurnal Bisnis dan Akuntansi Vol.19, No.1, Juni 2017.

Putri, V. R., \& Putra, N. I. (2017). Pengaruh Leverage, Profitability, Ukuran Perusahaa dan Proporsi Kepemilikan Terhadap Penghindaran Pajak. Jurnal Ekonomi Manajemen Sumber Daya Vol.19, No.1, Juni 2017, 2.

Rinaldi, \& Cheisviyanny, C. (2015). Pengaruh Profitabilitas, Ukuran perusahaan dan Kompensasi Rugi Fiskal Terhadap Tax Avoidance. SNEMA-2015.

Suandy, E. (2014). Hukum Pajak. Jakarta: Salemba Empat.

Suandy, E. (2016). Perencanaan Pajak Edisi 6. Jakarta: Salemba Empat.

Sugiyono. (2017). Metode Penlitian Bisnis . Bandung: Alfabeta.

Sundari, N., \& Aprilina, V. (2017). Pengaruh Konservatisme Akuntansi, Intensitas Aset Tetap, Kompensasi Rugi Fiskal dan Corporate Governance Terhadap Tax Avoidance. JRAK Vol.8 No. 1 Februari.

Waluyo. (2013). Perpajakan Indonesia. Jakarta: Salemba empat.

www.pajak.go.id diakses 30 Agustus 2018 